\title{
Economic and Welfare Impacts of Indonesia's Tourism Sector
}

Arif Haryana ${ }^{1}$

\author{
Ministry of National Development Planning (Bappenas) \\ Corresponding author. Email: haryana@bappenas.go.id
}

Submitted: July 01 2020 | Accepted: September $21^{\text {st }} 2020$ | Published: September $28^{\text {th }} 2020$

\begin{abstract}
This paper aimed to see the impact of the development of the tourism sector during Indonesia's MidTerm Development Planning Period (RPJMN) 2015-2019. The analysis also aimed to contribute to the Terminal Evaluation of RPJMN 2015-2019. The implementation of this impact evaluation analyzes the achievement of tourism's primary target sector to the national economy and the welfare of individual workers and business units engaged in the field of tourism. The impact on the national economy is evaluated based on relevant secondary data. While the impact analysis on the welfare of individual workers and the tourism business unit carried out using primary data obtained through surveys. The field survey was conducted on June-July 2019, covering all provinces, 2.125 individual workers, and 1.082 business units participate as respondents. The proportional sampling method was used to determine the number of respondents in each province. The study found that during 20142019, the competitiveness of the Indonesian tourism sector has increased and has encouraged the increasing number of foreign tourists to visit. The sector has experienced growth and contributes positively to the national economy. At the micro-level, the sector generated a positive impact on the tourism business unit as most of them were claiming to gain profit sustainably during that period. However, the impact was still limited in improving business units' ability to innovate in product development and the ability to generate new employment. There was also a minimal positive impact on the welfare of the sector's workers. In terms of the average earning per month, the welfare of workers in this sector is still relatively low compared to workers in all other sectors.
\end{abstract}

Keywords: Tourism; Economics of Tourism; Impact Evaluation

${ }^{1}$ Arif Haryana is a Principal Planner and Former Director of System and Reporting of Development Evaluation at National Development Planning Agency (Bappenas) - Indonesia. 


\section{Economic and Welfare Impacts of Indonesia's Tourism Sector}

Arif Haryana

\section{Introduction}

Evaluation is a systematic and objective assessment of the program's implementation and the ongoing or completed intervention activities. Evaluation needs to be precisely and measurable according to the logical framework of the development intervention, whether in the form of policies, programs, and development activities.

With the end of the development period RPJMN 2015-2019, it is necessary to evaluate the achievement of various targets and development targets. Also, it needs to evaluate the impact of development programs perceived by the community.

Tourism is considered as one of the priority sectors in national development in the 2014-2019 RPJMN. This sector is considered to have a sizeable economic linkage so that it can contribute significantly to the national economy. With this in mind, it is necessary to evaluate the performance of tourism development and its impacts on the national economy.

This impact evaluation analysis the achievement of the main target of the tourism sector on the national economy and the welfare of individual workers and business units engaged in tourism. The impact on the national economy was evaluated based on relevant secondary data. While the impact analysis on the micro-level of the welfare of individual workers and tourism business units, conducted using primary data obtained through surveys.

\section{Methodology}

The evaluation conducted in three main steps: Determination of indicators, Data Collection, and Data Analysis. The process framework is the workflow, as can be seen in Figure 1.
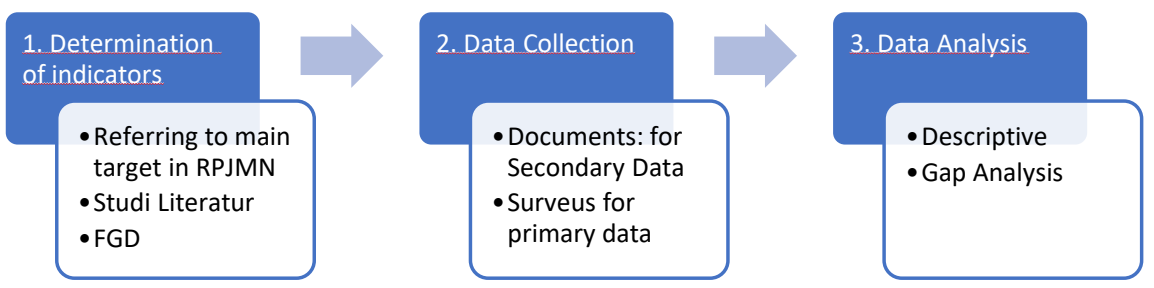

Figure 1. The process of the Impact Evaluation

\subsection{Determining of Impact Indicator}

The determination of the impact indicator refers to the main goal in RPJMN 20152019. Furthermore, significant targets were analyzed through literature and empirical studies to produce the right candidates for impact indicators. The impact indicator is chosen 
by taking proper impact indicator criteria and having a significant influence on the underlying target to be analyzed - the selection process conducted through the Focus Group Discussion (FGD) along with relevant experts and stakeholders.

\subsection{Data Collection and Analysis}

The data used in the evaluation consists of primary and secondary data; Primary data collected through field surveys covering all of the provinces. The field survey was undertaken on June-July 2019. The field surveys include 2,125 respondents of individual workers and 1.082 respondents of business units - the number of sample respondents determined by considering the population proportion of each province.

The survey conducted using questionnaires. The questionnaire for individual workers as well as for business unit developed separately. The questionnaire developed through discussions among the experts of Bappenas, line ministries, and universities as the survey team, the discussion conducted a series of workshops or FGD.

Secondary data collected from domestic and international sources, the domestic sources of data, are mainly the publications of Badan Pusat Statistik (BPS) and related institutions, including the Ministry of Tourism and Creative Economic. Data collected from the World Economic Forum (WEF) publications, notably the Travel \& Tourism Competitiveness Reports.

\section{Tourism Sector Impact Analysis Performance}

This section begins with a review of Indonesia's tourism competitiveness performance at the global level, followed by evaluating the impact of tourism sector development. The evaluation aimed to analyze the role of tourism sector development on two levels, macro and micro. At the macro level, this study analyzed the role of the tourism sector in the national economy and its potential contribution to the local economy. The micro-level evaluation conducted to see the impact on the welfare of the business entity and individual workers in the tourism sector.

\subsection{Competitiveness of Indonesia tourism}

Tourism is one of the sectors in the Indonesian economy that reasonably high competitiveness and continues to increase. According to the rating of the Travel and Tourism Competitiveness Index (TTCI) published by the World Economic Forum (WEF), Indonesia was rank $40^{\text {th }}$ (from 140 countries) in 2019 with an increasing trend. The position of competitiveness has been increasing by ten tiers from rank 50 (from 140 countries) in 2015. TTCI is an index that reflects the overall quality, future potential, and long-term sustainability of the tourism sector in every country assessed. It consists of four subindexes and 14 indicators, including Enabling Environment (consists of 5 indicators), Policy and Enabling Conditions (rank four indicators), Infrastructure (3 indicators), and Natural and Cultural Resources (2 indicators).

Increasing the competitiveness of the Indonesian tourism sector is the fruit of the policy that placed tourism as one of the priority sectors in national development. Indonesia was ranked $4^{\text {th }}$ in the Policy and Enabling Environment. It has also been supported by sustainable investment in the development of communication infrastructure and air 
transport, which supports the two main competitive advantages of Indonesia's tourism: the competitiveness of price and wealth of natural resources.

Based on the overall composite score index, Indonesia is still lag behind Singapore (rank 17), Malaysia (rank 29), and Thailand (rank 31). However, Indonesia is leading or in par with the average of the South-East Asian Countries in most indicators. Figure 2 depicts Indonesia's score and position in each indicator of the TTCI index and its relative position compared to the average South-East Asian Countries. From 14 indicators under consideration, Indonesia performs better or in par with the average South-East Asian Countries in 11 indicators. Indonesia is lagging in 3 indicators.

In the Enabling Environment subindex, Indonesia is still rated Low (ranked at 72), especially in two critical indicators, namely Health and Hygiene (rank 102) and Safety and Security (rank 80). Besides, the infrastructure subindex also still need improvement, especially in the Tourist Service Infrastructure (rank 98). The Tourist Services Infrastructure shows the capacity of the country as a host in accommodating and serving a large number of tourists well. This infrastructure includes the availability of hotel rooms, car rental companies, and even the number of ATMs. The expansion of the road network and road quality still needs to be improved.

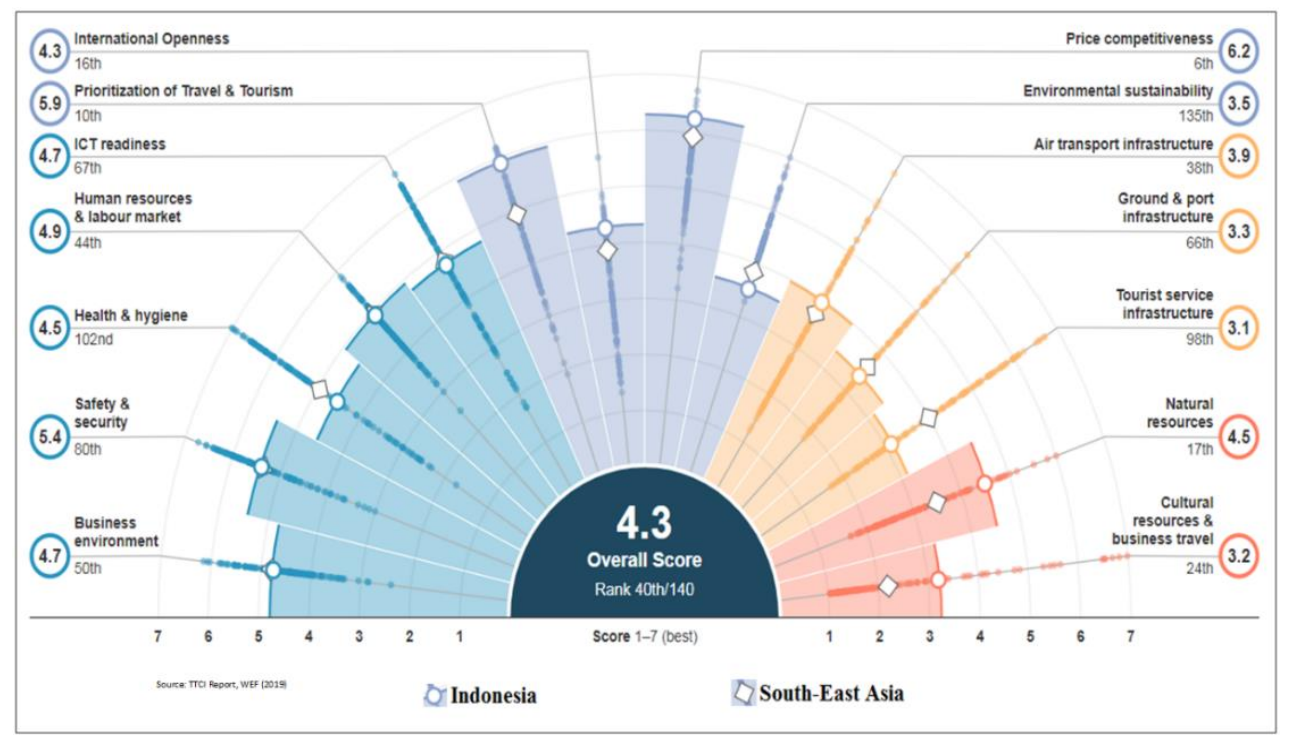

Figure 2. Tourism Competitiveness Performance of Indonesia Relative to the South-East Asian Countries

Source: TTCI Report, WEF (2019)

\subsection{Impact on the economy}

The impacts of tourism development can be measured from tourism contributions to the economy, including the Gross Domestic Products (GDP) and employment/labor absorption. From 2015 to 2018, the tourism sector's contribution to GDP has been increasing. The contribution had increased from 4.25 percent in 2015 to 4.50 percent in 2018. The tourism sector's contribution to GDP in 2019 was prognosed at around 5.50 percent. (Figure. 3) 
The role of the tourism sector in the national economy has been increasing sustainably. However, it was not large enough to reach the target of 8 percent contribution in 2019. The target has been stipulated in the RPJMN 2015-2019 and the Ministry of Tourism Strategic Planning (Renstra) for the period.

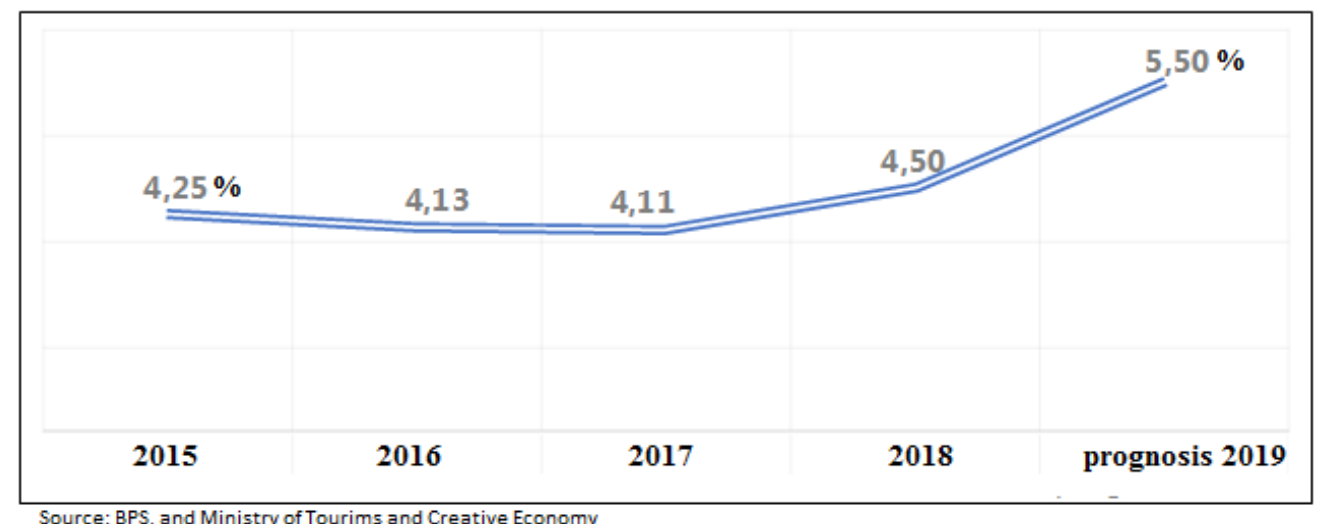

Figure 3. Tourism Sector contribution on GDP, 2015 - 2019 (Percent)

WTTC (2019) has provided a much higher figure of tourism contribution compared to BPS calculation data. According to the WTTC calculations (Figure 4), tourism GDP continues to evolve with an average growth of 9 percent per year. The tourism GDP increased from 61.45 trillion rupiahs to about 95.13 trillion rupiahs in 2018. In 2019, tourism GDP was estimated to grow at a rate of around 10 percent. Although the growth is quite high, the tourism contribution to GDP stagnates below 6 percent. Its contributions to GDP only increased by 0.05 percent, from 5.81 percent in 2014 to 5.86 percent in 2019. Although WTTC's calculation was higher than that of BPS, the contribution of tourism to the national economy is still lower than its target in 2019 in the RPJMN 2015-1019.

GDP growth of the tourism sector seems to be closely related to the number of foreign tourists visiting Indonesia. BPS (2020) reported that the number of foreign tourist visits increased by an average of 10 percent per year, from 10.23 million in 2015 to 16.11 million in 2019. This growth rate was similar to the GDP of the tourism sector. However, this figure is only 80 percent of the target of 20 million foreign tourist arrivals in 2019. This figure may provide the reason why the target of the sector's contribution to GDP not achieved. Anggraeni (2017) and Öztürk et al. (2019) findings in their research using data from ASEAN-8 Countries, Anggraeni's analysis revealed that the number of international tourist arrivals have a significant effect on economic growth. Öztürk et al. (2019) also reported that there are significant relations between GDP, export, and tourism in ASEAN member countries.

The role of the tourism sector in employment can also be reviewed from the BPS data. BPS (2017) shows that as much as 12.74 million people has been working in the tourism sector. Most of them (93.4 percent) are with the background of high school education or lower. Another publication of BPS (2019) reported that the tourism sector's contribution to labor absorption has been increasing continuously, from 9 percent in 2015 to 10.1 percent in 2019. Labour absorption has always been more significant than the contribution to GDP. 
By comparing the trend of both the sector's contribution on GDP and labour absorption, it seems that the productivity and welfare of workers engaged in the sector was not improving. Figure 2 depict clearly that the tourism sector's contribution in labour absorption was always higher than its contribution to GDP. Moreover, the tourism sector's contribution in labour absorption tends to increase more rapidly than its contribution in the formation of GDP. Based on this information it could be presumed that labour productivity of tourism sector did not improving, or even tended to decline. Stagnated or decreased worker productivity will impact the low welfare of workers. The fact that most workers in this sector have a low level of education is likely to contribute to low productivity of labour.

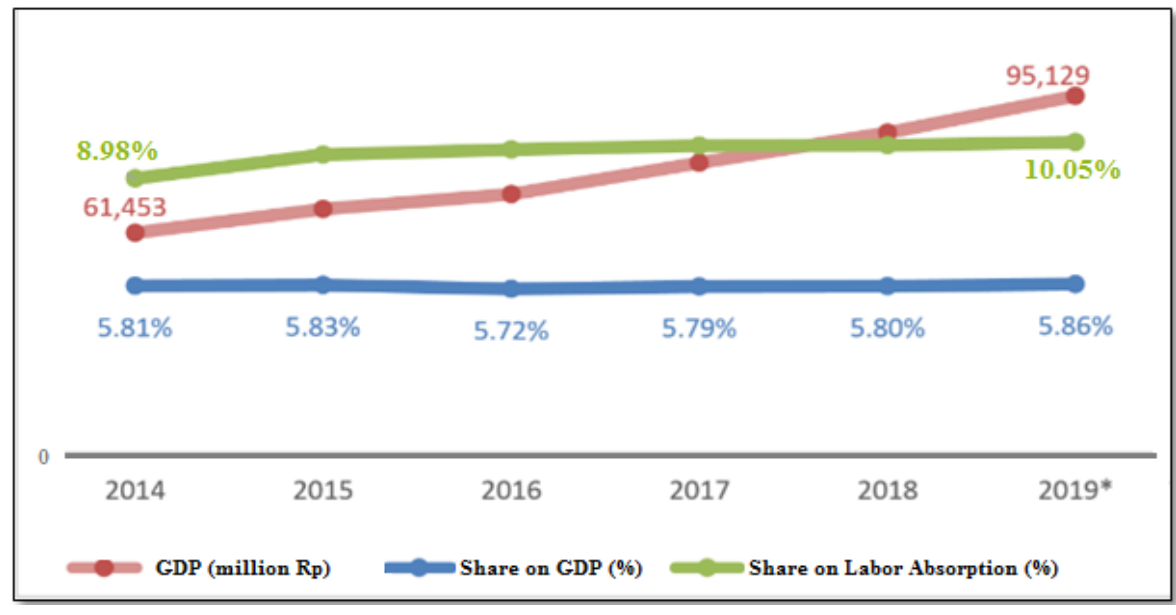

Figure 4. Tourism contributions on GDP and labour absorption.

Source: WTTC, 2019

Tourism has an increasing role in the regional economy. Its contribution is quite significant in some provinces. Tourism contributes significantly to the economy in the provinces of Bali, Yogyakarta, East Java, Central Java, and DKI Jakarta. During 2014-2018, the sector contributions in the Gross Domestic Regional Product (GDRP) have been increased in most of the provinces, except DKI Jakarta and West Nusa Tenggara provinces which was decreased. In addition to the considerable contribution of tourism sector in the GDRP, the growth in the 2014-2018 period is also higher than other regional areas. (Table 1). This indicates that tourism economic activity is still concentrated in the island of Java and Bali.

Table 1 also shows that the tourism sector will play an instrumental role in the economy in some areas because it has a considerable increase in the GDRP of the sector. There are provinces that demonstrate considerable development of tourism, including Bengkulu, Lampung, Kepulauan Riau, North Sulawesi, North Kalimantan, and North Sumatera. This development is supported by various innovations in the area of tourism. 
Table 1. Tourism contributions to GDRP in 34 provinces (\%)

\begin{tabular}{|c|c|c|c|c|c|c|}
\hline Province & 2014 & 2015 & 2016 & 2017 & 2018 & $\begin{array}{l}\text { Changed } \\
2014-2018\end{array}$ \\
\hline $\mathrm{ACEH}$ & 1,06 & 1,14 & 1,19 & 1,27 & 1,32 & 0,26 \\
\hline SUMATERA UTARA & 2,20 & 2,24 & 2,27 & 2,31 & 2,37 & 0,17 \\
\hline SUMATERA BARAT & 1,00 & 1,01 & 1,05 & 1,09 & 1,12 & 0,12 \\
\hline RIAU & 0,44 & 0,45 & 0,45 & 0,46 & 0,47 & 0,02 \\
\hline |AMBI & 1,02 & 0,98 & 1,00 & 1,03 & 1,06 & 0,04 \\
\hline SUMATERA SELATAN & 1,13 & 1,19 & 1,25 & 1,28 & $\mathrm{n} / \mathrm{a}$ & 0,15 \\
\hline BENGKULU & 1,45 & 1,50 & 1,56 & 1,63 & 1,67 & 0,27 \\
\hline LAMPUNG & 1,27 & 1,32 & 1,34 & 1,38 & 1,45 & 0,18 \\
\hline KEP, BANGKA BELITUNG & 2,27 & 2,25 & 2,27 & 2,27 & 2,31 & 0,04 \\
\hline KEPULAUAN RIAU & 1,94 & 1,94 & 1,94 & 2,13 & 2,26 & 0,32 \\
\hline DKI JAKARTA & 5,01 & 4,99 & 4,99 & 4,98 & 4,94 & $(0,06)$ \\
\hline IAWA BARAT & 2,40 & 2,47 & 2.55 & 2,63 & 2.69 & 0.29 \\
\hline IAWA TENGAH & 3,07 & 3,11 & 3.14 & 3.17 & 3.26 & 0.19 \\
\hline DIYOGYAKARTA & 9,32 & 9,39 & 9.44 & 9,52 & 9.57 & 0.25 \\
\hline JAWA TIMUR & 4,97 & 5,08 & 5,22 & 5,34 & 5.45 & 0,48 \\
\hline BANTEN & 2,29 & 2,31 & 2,36 & 2,42 & 2,46 & 0,17 \\
\hline BALI & 19.55 & 19,60 & 19,65 & 20,30 & 20,27 & 0.72 \\
\hline NUSA TENGGARA BARAT & 1.81 & 1,57 & 1.64 & 1.75 & 1.75 & $(0,06)$ \\
\hline NUSA TENGGARATIMUR & 0,59 & 0,60 & 0,65 & 0.70 & 0.75 & 0,16 \\
\hline KALIMANTAN BARAT & 2.29 & 2,31 & 2,29 & 2.26 & 2,30 & 0,01 \\
\hline KALIMANTAN TENGAH & 1.65 & 1,67 & 1,70 & 1,68 & 1,70 & 0,05 \\
\hline KALIMANTAN SELATAN & 1,80 & 1,85 & 1,89 & 1,92 & 1,95 & 0,15 \\
\hline KALIMMANTAN TIMUR & 0,68 & 0,74 & 0,79 & 0,84 & 0,89 & 0,21 \\
\hline KALIMANTAN UTARA & 1,20 & 1,24 & 1,29 & 1,37 & 1,45 & 0,25 \\
\hline SULAWESI UTARA & 2,14 & 2,19 & 2,32 & 2,33 & 2,32 & 0,18 \\
\hline SULAWESI TENGAH & 0.55 & 0,53 & 0,51 & 0,51 & 0,51 & $(0,04)$ \\
\hline SULAWESI SELATAN & 1.36 & 1.34 & 1.36 & 1.42 & 1.49 & 0,13 \\
\hline SULAWESI TENGGARA & 0.57 & 0,58 & 0,58 & 0,58 & 0,58 & 0,01 \\
\hline GORONTALO & 2,15 & 2,19 & 2,23 & 2,32 & 2,34 & 0,19 \\
\hline SULAWESI BARAT & 0,24 & 0,24 & 0,25 & 0,24 & 0,24 & 0,00 \\
\hline MALUKU & 1,80 & 1,83 & 1,73 & 1,71 & 1,69 & $(0,11)$ \\
\hline MALUKU UTARA & 0,44 & 0,43 & 0,46 & 0,47 & 0,46 & 0,02 \\
\hline PAPUA BARAT & 0,49 & 0,51 & 0,52 & 0,54 & 0,55 & 0,06 \\
\hline PAPUA & 0,68 & 0,68 & 0,66 & 0,67 & 0,66 & $(0,02)$ \\
\hline INDONESIA & 5,81 & 5,83 & 5,72 & 5,79 & 5,80 & 5.79 \\
\hline
\end{tabular}

Source: Badan Pusat statistik, 2019.

\subsection{Impact on the Business Unit and Individual Workers}

This analysis is also done on a micro level to see the perceived impact of business units and tourism workers on the development of tourism sector. The impact on the micro level was measured through surveys of companies and workers engaged in tourism services.

\section{A. Impact on tourism business units}

The question of whether the company measured the impact of the tourism sector development perceived by the business unit have gained profit sustainably, able to diversify or improve the product/service and increase sales, and had carried out the recruitment of new hires. 
The survey showed that almost all companies in tourism services (more than 95 percent) received sustained gains over a period from 2015 to 2019 (Fig. 5). Even in 2017, only two percent of the business unit claimed to be not profitable. This fact shows that the development of the tourism sector has a positive impact on the business. Although the majority of companies benefit from business, there is no information about the amount of corporate profits surveyed.

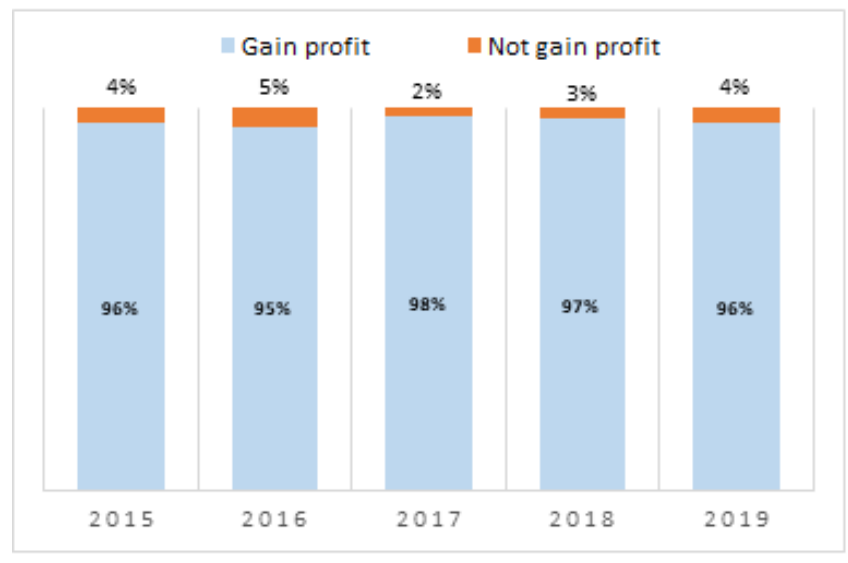

Figure 5. Proportion of Tourism Business Gaining Profit

Source: Survey Data Bappenas, 2019

Almost all business units claimed gaining benefit sustainably during 2014-2019. However, the impact is still relatively limited, especially if we view it in the term of the sales volume and changes in the product type. Figure 6 (A) provides an overview of the changes experienced by the tourism company in terms of sales volume and product type diversification during 2014-2019. Figure 6 (B) shows the change in the number of business units that conducted recruitment of new employees between the period 2010-2014 and 20152019.

In Figure 6(A), it is seen that most (67 percent) of tourism business units did not experience an increase in sales volume, even among them there are 7 percent of business units experienced sales volume decrease. Of the tourism business unit surveyed only 33 percent claimed their sales volume increased.

In addition, in most business units ( 81 percent) there is no improvement in the type of products being marketed. Only 19 percent of business units has been improving the diversification of their product. This is an indication that tourism business still has limitations on product development innovations. The limitations of this product development innovation may be one of the reasons why few business units can increase the volume of sales. They need greater support and encouragement to develop their capacity to innovate.

The limited product development and sales volume during 2014-2019 also impacted the limited business unit of the sector in creating new jobs. Figure 6 (B) shows the ability of a business unit in recruiting new employees in 2015-2019 and 2010-2014 period was not improving. The number of business units hiring new employees in 2015-2019 reaches 66 percent, lower than in the 2010-2014 period, although the difference is not very significant. 
This is an indication that the impact of the development of the tourism sector has not been able to improve the business unit's ability to create new employment.

The development of the tourism sector has positively impacted business units in gaining profit. However, the impact has not been large enough to be able to improve the ability of business units to innovate in product development and the ability to create new employment.

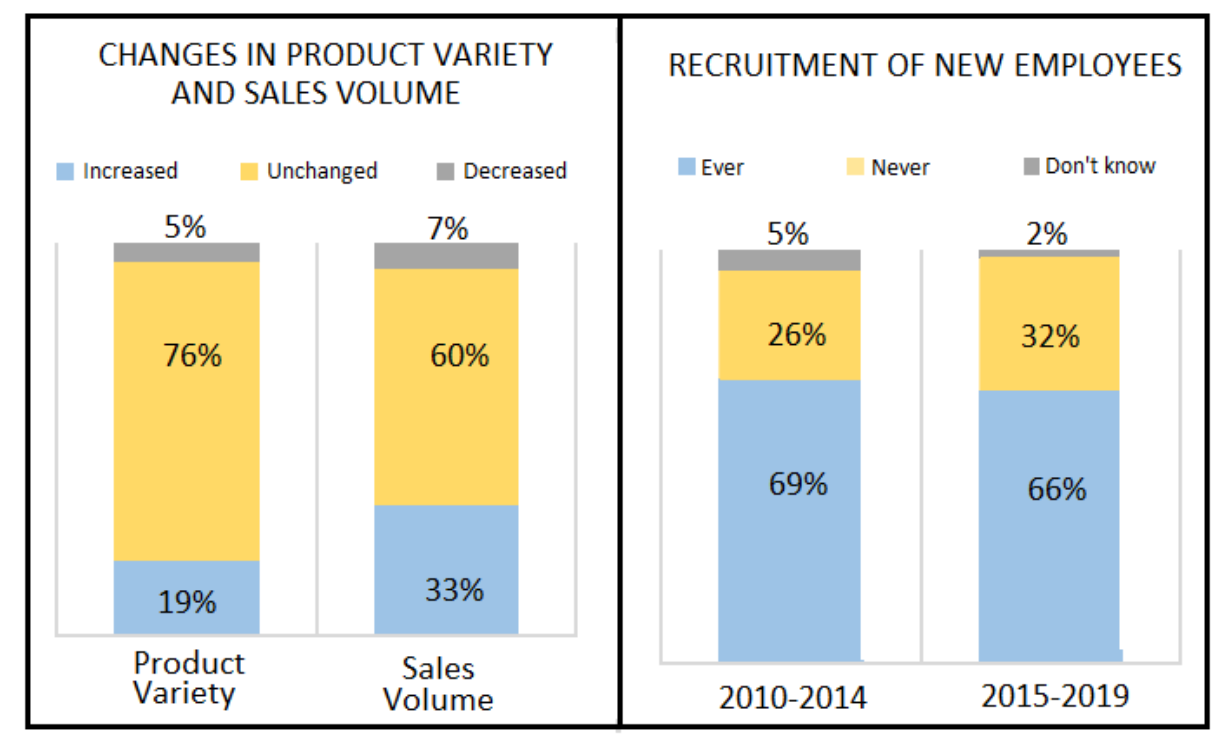

(A)

(B)

Figure 6. Impact of Tourism Development Program on Business Unit

(A) Changes in product type and Sales Volume

(B) Employee recruitment at Tourism Business Unit

Source: Survey Data Bappenas, 2019

\section{B. Impact on tourism workers}

The development of tourism sector is expected to provide welfare for working individuals. An important indicator that demonstrates well-being is the amount of monthly income earned, and how it compares to the general worker's income. Individuals surveyed were asked to answer what field of employment they engaged in and how much monthly earnings they received. A total of 1263 respondents answered the questionnaire, including 19 percent of those are working on the field of tourism. The proportion of employees by monthly wages in the field of tourism is compared to the overall workers in all field of works. The result is summarized in Table 2 . 
Table 2. Proportion of total employee responses by monthly wages groups (\%)

\begin{tabular}{lcc}
\hline $\begin{array}{l}\text { Monthly wage }(\mathrm{W}) \text { in } \\
\text { Rupiah }\end{array}$ & Overall Workers & Tourism Workers \\
\hline Do not know & 10.9 & 1.3 \\
$\mathrm{~W} \geq 20$ million & 9.9 & 0.4 \\
$10 \geq \mathrm{W} \leq 20$ million & 0.3 & 0.9 \\
$5 \geq \mathrm{W} \leq 10$ million & 1.4 & 2.7 \\
$2 \geq \mathrm{W} \leq 5$ million & 8.5 & 9.8 \\
$1 \geq \mathrm{W} \leq 2$ million & 36.6 & 48.7 \\
$0.5 \geq \mathrm{W} \leq 1$ million & 19.6 & 22.3 \\
$\mathrm{~W}<0.5$ million & 12.7 & 13.8 \\
\hline
\end{tabular}

Source: Result of survey, Bappenas, 2019

Table 2 provides an overview of the monthly average wage comparison of workers in the tourism sector in all sectors. On the average, wages received by tourism workers was lower than the average wage of the overall worker in all sectors.

Lets assume that the wage of two million rupiahs permonth as the benchmark in determining low wage rate. The wage of less than this figure is considered as low. The basis for the assumption is the BPS data. BPS (2020) reported that the lowest average wage in 2019 was 2.11 million rupiahs, which was the case of the province of Nusa Tenggara Timur. BPS also reported the average wage for services works in informal sector in 2019 was 2.17 million rupiahs. Therefore, it does make sense if we consider 2 million rupiahs as the benchmark in determining low wage.

Based on these benchmarks, the survey results in Table 2 show that the majority of workers engaged in the tourism sector (84.8 percent) have received low monthly wages (less than two million rupiah). This proportion is far greater than all sector workers, which is around 68.9 percent. This implies that the welfare of workers in tourism is no better than in other sectors. The findings from this micro-level analysis that tourism workers get low wages, which also implies a low level of welfare, was consistent with- and confirmed the indications in the macro-level analysis that the productivity and welfare of workers involved in the sector are not improving. The low level of education and skills of tourism workers can be one of the main affecting factors. It needs to improve human resource capacity and capability through education and trainings.

\section{Conclusion and Policy Impliocations}

\subsection{Conclusions}

The conclusions derived from the above analysis and discussions are:

1. The competitiveness of the Indonesian tourism sector during 2014-2019 has been increasing and has encouraged the increasing number of foreign tourists to visit. However, it is lagging behind the significant South-East Asian countries. 
2. Lacking of tourist service infrastructure and low-rated health and hygiene are the main factor that lowering Indonesia competitiveness in attracting foreign tourists.

3. The tourism sector has experienced growth and contributes positively to the national economy. But such growth is not large enough to be able to achieve the target of increasing its contribution to the national economy.

4. The development of the tourism sector has positively impacted the tourism business unit in obtaining profits, but still has not had a big impact on improving the ability of business units to innovate in product development and the ability to create new employment.

5. In general, tourism business is able to gain profit, but the welfare of workers in this sector is still relatively low. This is related to the low level of education and skills.

\subsection{Policy Implications}

Considering the weaknesses that were found in the analysis, there are policy implications that should be taken into consideration in order to improve tourism sector contribution in the economy and welfare of workers engaged in. These are:

1. Continuing policy that prioritizes tourism in the national development

2. Improving the competitiveness of Indonesia Tourism by providing a more dependable and quality of tourist service infrastructure and improve the health and hygiene indicator.

3. Improving human resource capacity and capability through better education and trainings, especially vocational education and training to support the hospitality business.

\section{References}

Anggraeni, G. N. 2017. The Relationship between Numbers of International Tourist Arrivals and Economic Growth In The ASEAN-8: Panel Data Approach. Journal of Developing Economies 02(1): 40-49. (https://ejournal.unair.ac.id/JDE/article/view/5118/3737)

BPS.2020. Statistik Indonesia 2020.

(https://www.bps.go.id/publication/download.html?nrbvfeve=ZTkwMTFiMz E1NWQONWQ3MDgyM2MxNDFm\&xzmn=aHRocHM6Ly93d3cuYnBzLmd vLmlkL3B1YmxpY2FoaW9uLzIwMjAvMDQvMjkvZTkwMTFiMzE1NWQo NWQ3MDgyM2MxNDFmL3NoYXRpc3Rpay 1 pbmRvbmVzaWEtMjAyMC50 dG1s\&twoadfnoarfeauf=MjAyMCOwNioxMSAxNjowOTooMg\%3D\%3D)

BPS.2020. Garis Kemiskinan Menurut Provinsi, 2013 - 2019. https://www.bps.go.id/dynamictable/2016/01/18/1120/garis-kemiskinanmenurut-provinsi-2013---2019.html

BPS.2019 Neraca Satelit Pariwisata Nasional 2017 (NESPARNAS 2017). https://www.bps.go.id/publication/download.html?nrbvfeve=NjY2MDRlOW 
YwNzc5ODNjMTViODBlMmJj\&xzmn=aHRocHM6Ly93d3cuYnBzLmdvLml kL3B1YmxpY2FoaW9uLzIwMTkvMDMvMjYvNjY2MDRlOWYwNzc5ODN jMTViODBlMmJjL25lcmFjYS1zYXRlbGloLXBhcml3aXNhdGEtbmFzaW9u YWwtLW5lc3Bhem5hcyotMjAxNyOuaHRtbA\%3D\%3D\&twoadfnoarfeauf=Mj AyMCOwNSowOCAxMzoyNzoxOA\%3D\%3D

BPS.2018. Statistik Kunjungan Wisatawan Mancanegara 2017. https://www.bps.go.id/publication/download.html?nrbvfeve=NzcoODBjYWN kYjBhMzlhYmEzZGU4NGNl\&xzmn=aHRocHM6Ly93d3cuYnBzLmdvLmlkL 3B1YmxpY2FoaW9uLzIwMTgvMDkvMTQvNzcoODBjYWNkYjBhMzlhYm EzZGU4NGNIL3NoYXRpc3Rpay1rdW5qdW5nYW4td2lzYXRhd2FuLW 1hb mNhbmVnYXJhLTIwMTcuaHRtbA\%3D\%3D\&twoadfnoarfeauf=MjAyMCOw NSowOCAxNDoyMDozOQ\%3D\%3D

BPS.2017. Kajian Data Pasar Pariwisata Nusantara 2017. http://www.kemenparekraf.go.id/asset_admin/assets/uploads/media/pdf/medi a_1553500574_Publikasi_Kajian_Data_Pasar_Wisnus_2017.pdf

Öztürk M., Ihtiyar A., Aras O.N. 2019. The Relationship Between Tourism Industry and Economic Growth: A Panel Data Analysis for ASEAN Member Countries. In: Rezaei S. (eds) Quantitative Tourism Research in Asia. Perspectives on Asian Tourism. Springer, Singapore (https://link.springer.com/chapter/10.1007/978981-13-2463-5_3)

WEF. 2019. The Travel \& Tourism Competitiveness Report 2019: Travel and Tourism at a Tipping Point (http://www3.weforum.org/docs/WEF_TTCR_2019.pdf) \& (https://reports.weforum.org/travel-and-tourism-competitiveness-report2019/country-profiles/\#economy=IDN)

WEF. 2015. The Travel \& Tourism Competitiveness Report 2015: Growth through Shocks (http://www3.weforum.org/docs/TT15/WEF_Global_Travel\&Tourism_Repo rt_2015.pdf) 